Volume 11 Number 1 May 2021 Page. 39-50

Journal Homepage : http://teknois.stikombinaniaga.ac.id/index.php/JBS

DOI Link : http://doi.org/10.36350/jbs.v11i1

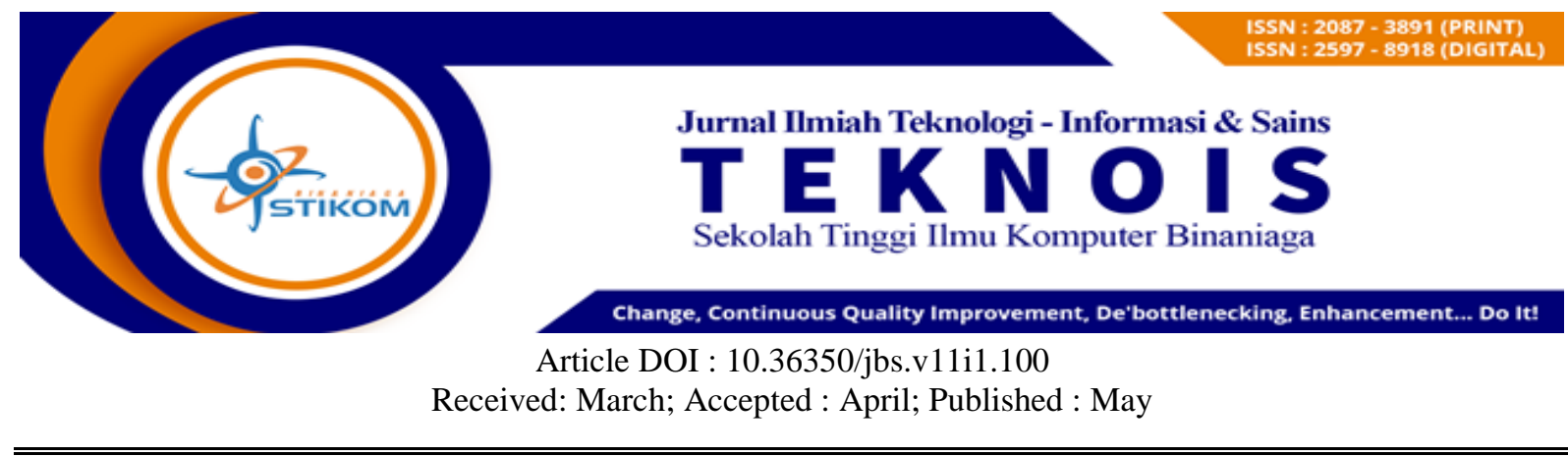

\title{
Penerapan Metode Perbandingan Eksponensial (MPE) untuk Penentuan Person in Charge (PIC) Teknisi
}

\author{
Rajib Ghaniy $^{1^{*}}$, Edi Haryadi ${ }^{2}$ \\ ${ }^{1}$ Sistem Informasi/STIKOM Binaniga \\ Email: rajib@stikombinaniaga.ac.id \\ ${ }^{2}$ Sistem Informasi/STIKOM Binaniga \\ Email: eharyadi37@gmail.com
}

\begin{abstract}
PT. MRK Diagnostics is a company engaged in the health sector, especially the provider of medical laboratory equipment in Indonesia. Determination of technicians who are currently running to deal with damage to medical devices is still ineffective because the determination is still checking the availability of technicians manually, so that it will make handling the damage slower. Therefore we need a system that can assist in determining the person in charge technicians to repair the tool. So that in determining the person in charge, this technician will be able to be done precisely and quickly. The criteria used to determine PIC are expertise, discipline, communication and years of service. Each criterion has sub-criteria as well as predetermined weights and values. The decision support system to determine the person-in-charge technicians for medical device repair uses an exponential comparison method that generates a list of priority technicians to perform equipment repair based on calculated and compared values System testing is carried out on information systems experts and users using a questionnaire instrument. Based on expert information systems testing, this system is declared very feasible with a value of $91.7 \%$ of the results of system expert testing and $80 \%$ based on user testing.
\end{abstract}

Keywords: PIC; MPE; Criteria; Appropriateness.

\section{ABSTRAK}

PT. MRK Diagnostics adalah perusahaan yang bergerak dalam bidang kesehatan, khususnya penyedia alat-alat laboratorium kesehatan di Indonesia. Penentuan teknisi yang saat ini berjalan untuk menangani kerusakan alat kesehatan saat ini masih belum efektif karna penentuannya masih melakukan pengecekan ketersedian teknisi secara manual, sehingga akan membuat penanganan kerusakan akan lebih lambat. Oleh sebab itu diperlukan suatu sistem yang dapat membantu dalam penentuan person in charge teknisi untuk perbaikan alat tersebut. Sehingga dalam penentuan person in charge teknisi ini akan dapat dilakukan dengan tepat dan cepat. Kriteria yang digunakan untuk penentuan PIC yaitu keahlian, disiplin, komunikasi dan masa kerja. Setiap kriteria memiliki subkriteria serta bobot dan nilai yang telah ditentukan. Sistem pendukung keputusan untuk menentukan person in charge teknisi untuk perbaikan alat kesehatan menggunakan metode perbandingan eksponensial yang menghasilkan daftar teknisi yang menjadi prioritas untuk melakukan perbaikan alat berdasarkan nilai yang sudah dihitung dan dibandingkan. Pengujian sistem dilakukan kepada ahli sistem informasi dan pengguna dengan menggunakan instrumen kuisioner. Berdasarkan pengujian ahli sistem informasi, sistem ini dinyatakan sangat layak dengan nilai $91.7 \%$ dari hasil pengujian ahli sistem dan $80 \%$ berdasarkan pengujian pengguna.

Keywords: PIC; MPE; Kriteria; Kelayakan. 


\section{A. PENDAHULUAN}

\section{Latar Belakang}

Person in charge adalah seseorang yang bertugas menangani tugas tertentu di dalam perusahaan, organisasi maupun institusi. Dalam penentuan person in charge ini tentunya bukan dipilih secara tanpa alasan, pastinya penentuan person in charge ini memiliki kriteria tertentu di setiap perusahaan ataupun organisasi. Karna dengan penentuan PIC yang tepat tentunya akan membuat tugas yang diberikan akan dapat diselesaikan dengan baik dan tepat waktu.

Apabila penentuan PIC ini tidak tepat, pekerjaan tersebut akan terselesaikan dengan waktu yang lebih lama dan juga akan membuat pemborosan sumber daya manusia yang menangani pekerjaan tersebut. Karna apabila PIC yang dipilih ternyata tidak berkompeten terhadap tugas yang diberikan pasti akhirnya akan membutuhkan tenaga kerja atau petugas yang lebih memahami.

Layanan purna jual merupakan suatu hal yang penting bagi suatu perusahaan, bagaimana dengan layanan purna jual ini konsumen akan menjadi loyal terhadap perusahaan dan produk yang dijual. Bagaimana perusahaan dapat memberikan layanan purna jual yang cepat dan akurat sehingga akan berimbas terhadap kepuasan konsumen kepada perusahaan. Salah satu layanan purna jual adalah layanan servis, bagaimana perusahaan itu memberikan layanan servis untuk produk yang di jual dan juga memberikan servis yang terbaik untuk konsumen.

Metode Perbandingan Eksponensial (MPE) merupakan sistem pendukung keputusan yang digunakan untuk menentukan prioritas alternative berdasarkan kriteria-kriteria yang ada. MPE pada dasarnya adalah metode scoring pada pilihan-pilihan yang ada sehingga akan didapatkan hasil pilihan berdasarkan skor tertinggi. Dalam penentuan PIC tentunya ada kriteria-kriteria yang harus dipenuhi. Sehingga pemilihan PIC akan efektif. Dengan MPE kriteria-kriteria tersebut masing -masing akan di scoring hingga akan mendapatkan kriteria dengan skor tertinggi.

Metode perbandingan eksponensial (MPE) merupakan bagian sistem penunjang keputusan yang bisa digunakan dalam penentuan lokasi industri, penentuan asuransi atau bahkan untuk menentukan pembelian mobil bekas berdasarkan penelitian sebelumnya.

\section{Permasalahan}

Sejak bulan Januari hingga Desember 2018 terhitung ada sekitar 672 record kerusakan alat yang terjadi. Jika di hitung rata-rata perbulan sekitar 56 record kerusakan alat setiap bulannya. Dengan jumlah teknisi sebanyak 15 orang, tentunya dengan record kerusakan alat sekitar 56 record perbulannya dapat dipastikan akan mengalami kesulitan untuk menangani semua kerusakan alat tersebut. Dalam penentuan PIC ini ada dua kategori yaitu maintenance dan service. Maintenance adalah perawatan berkala terhadap alat-alat rumah sakit, sedangkan service merupakan tindakan yang dilakukan berdasarkan kerusakan atau keluhan yang terjadi pada alat. Penanganan service sendiri seringkali masih terjadi pemborosan sumber daya manusia dimana dalam satu kasus kerusakan alat ada dua orang teknisi yang menjadi PIC. Hal ini terjadi karena PIC teknisi yang dipilih atau ditugaskan justru kurang menguasai masalah kerusakan yang dihadapi, sehingga justru akan memanggil teknisi lain yang lebih menguasai kerusakan yang terjadi. Tentunya hal ini selain akan berdampak terhadap ketidak efektif-an dalam penanganan kerusakan alat tersebut. Berbeda dengan halnya apabila alat yang mengalami kerusakan adalah alat yang memiliki dimensi yang besar maka memang sangat diperlukan untuk penanganan yang lebih dari satu orang teknisi. Maka masalah yang dapat diidentifikasi yaitu:

a. Belum tepatnya dalam penentuan person in charge (PIC) untuk menangani kerusakan alat.

b. Proses penentuan PIC teknisi yang tidak efektif.

\section{Tujuan}

Adapun tujuan dari penelitian ini adalah : 
a. Membuat penentuan person in charge (PIC) untuk menangani kerusakan alat menjadi lebih efektif.

b. Mengembangkan aplikasi dengan menerapkan Metode Perbandingan Ekponensial MPE) untuk penentuan person in charge (PIC) teknisi.

\section{Tinjauan Pustaka}

\section{a. Sistem Pendukung Keputusan}

Decision Support Sistem adalah sistem informasi pendukung keputusan yang berbasis komputer yang digunakan dalam pengambilan keputusan dalam suatu organisasi atau perusahaan, dengan tujuan untuk meningkatkan efektifitas dalam pengambilan suatu keputusan

Sistem pendukung keputusan bertujuan untuk menyediakan informasi, membimbing, memberikan prediksi serta mengarahkan kepada pengguna informasi agar dapat melakukan pengambilan keputusan agar lebih baik. Tujuan sistem pendukung keputusan yang dikemukakan oleh Keen dan Scott dalam buku Sistem Informasi Manajemen (raymond McLeod, 2001) mempunyai tiga tujuan yang akan dicapai adalah:

1) Membantu manajer membuat keputusan untuk memecahkan masalah semi terstruktur

2) Mendukung penilaian manajer bukan menggantikannya.

3) Meningkatkan efektifitas pengambilan keputusan manajer daripada efesiensinya.

\section{b. Metode Perbandingan Eksponensial (MPE)}

Menurut Heny Pratiwi, dalam bukunya berjudul Buku Ajar Sistem Pendukung Keputusan (2016: 109). Metode Pebandingan Eksponensial (MPE) merupakan salah satu metode untuk menentukan urutan prioritas alternative keputusan dengan kriteria majemuk. Teknik ini digunakan sebagai pembantu bagi individu pengambil keputusan untuk menggunakan rancang bangun model yang telah terdefinisi dengan baik pada tahapan proses.

Langkah-langkah yang perlu dilakukan dilakukan dalam pemilihan keputusan dengan menggunakan MPE adalah:

1) Menyusun alternatif - alternatif keputusan yang akan dipilih

2) Menentukan kriteria atau perbandingan relatif kriteria keputusan yang penting untuk dievaluasidengan menggunakan skala konversi tertentu dengan keinginan pengambil keputusan.

3) Menentukan tingkat kepentingan relatif dari setiap kriteria keputusan atau pertimbangan kriteria. Penentuan bobot ditetapkan pada setiap kriteria untuk menunjukan tingkat kepentingan suatu kriteria.

4) Melakukan penilaian terhadap semua alternatif pada setiap kriteria dalam bentuk total skor tiap alternatif.

5) Menghitung skor atau nilai total setiap alternative dan mengurutkannya. Semakin besar Total Nilai (TN) alternative maka semakin tinggi urutan prioritasnya.

Formulasi perhitungan total nilai untuk setiap alternative dalam Metode Perbandingan Eksponensial adalah sebagai berikut:

$$
\text { Total Nilai }\left(T_{i}\right)=\sum_{j=1}^{m}\left(R^{m} i j\right)^{T K K_{j}}{ }_{s} 1 \leq i \leq n
$$

Dengan:

$\mathrm{TNi}=$ Total nilai alternatif ke-i

$\mathrm{RKi}=$ Derajat kepentingan relative kriteria ke-j pada pilihan keputusan $\mathrm{i}$

$\mathrm{TKKj}=$ Derajat kepentingan kriteriia keputusan ke-j; $\mathrm{TKKj}>0$; bulat

$\mathrm{N}=$ Jumlah alternatif pilihan keputusan

$\mathrm{M} \quad=$ Jumlah kriteria keputusan

Penentuan tingkat kepentingan kriteria dilakukan dengan cara wawancara dengan pakar atau melalui kesepakatan curah pendapat. Sedangkan penentuan skor alternatif pada 
kriteria tertentu dilakukan dengan memberi nilai setiap alternatif berdasarkan nilai kriterianya. Semakin besar nilai alternatif, semakin besar pula nilai alternatif tersebut. Total skor masing-masing alternatif keputusan akan relatif berbeda secara nyata karena adanya fungsi eksponensial. (Pratiwi, 2016).

Metode perbandingan eksponensial dapat mengurangi bias yang mungkin terjadi dalam analisis. Nilai skor yang menggambarkan urutan prioritas menjadi besar dalam hal fungsi eksponensial ini menyebabkan urutan prioritas alternatif keputusan menjadi lebih nyata.

\section{c. Prototype}

Menurut Raymond McLeod, prototype didefinisikan sebagai alat yang memberikan ide bagi pembuat maupun pemakai potensial tentang cara system berfungsi dalam bentuk lengkapnya, dan proses untuk menghasilkan sebuah prototype sisebut prototyping.

Prototyping perangkat lunak (software prototyping) atau siklus hidup menggunakan protoyping (life cycle using prototyping) adalah salah satu metode siklus hidup sistem yang didasarkan pada konsep model bekerja (working model). Tujuannya adalah mengembangkan model menjadi sistem final. Artinya sistem akan dikembangkan lebih cepat dari pada metode tradisional dan biayanya menjadi lebih rendah, dengan prototype yang terbuka, model sebuah sistem (atau bagiannya) dikembangkan secara cepat dan dipoles dalam diskusi yang berkali-kali dengan klien. Model tersebut menunjukkan kepada klien apa yang akan dilakukan oleh sistem, namun tidak didukung oleh rancangan desain struktur yang mendetil.

Protoyping membantu dalam menemukan kebutuhan di tahap awal pengembangan, terutama jika klien tidak yakin dimana masalah berasal. Selain itu protoyping juga berguna sebagai alat untuk mendesain dan memperbaiki user interface-bagaimana sistem akan terlihat oleh orang-orang yang menggunakannya.

Tahapan-tahapan dalam Prototyping adalah sebagai berikut:

1) Pengumpulan kebutuhan

2) Membangun prototyping

3) Evaluasi protoptyping

4) Mengkodekan system

5) Menguji system

6) Evaluasi Sistem

7) Menggunakan sistem

\section{B. METODE}

Pada penelitian ini model / metode yang akan diusulkan dibedakan menjadi dua, yaitu model konseptual dan model prosedural.

\section{Model Konseptual}

Metode Pebandingan Eksponensial (MPE) merupakan salah satu metode untuk menentukan urutan prioritas alternative keputusan dengan kriteria majemuk. Teknik ini digunakan sebagai pembantu bagi individu pengambil keputusan untuk menggunakan rancang bangun model yang telah terdefinisi dengan baik pada tahapan proses.

Langkah-langkah yang perlu dilakukan dalam pemilihan keputusan dengan menggunakan MPE adalah:

a. Penentuan alternatif keputusan.

b. Penyusunan kriteia keputusan yang akan dikaji.

c. Penentuan tingkat kepentingan relatif dari setiap kriteria keputusan atau pertimbangan kriteria. Penentuan bobot ditetapkan pada setiap kriteria keputusan dengan menggunakan skala konversi tertentu sesuai keinginan pengambil keputusan.

d. Penentuan derajat kepentingan relatif dari setiap alterntif keputusan.

e. Menghitung skor atau nilai total setiap alterntif dan mengurutkannya. Semakin besar Total Nilai (TN) alternatif maka akan semakin tinggi urutan prioitasnya. 


\section{Model Prosedural}

Model prosedural yang akan digunakan pada penelitian ini adalah dengan menggunakan metode prototyping. Menurut Raymond McLeod (Sidik: 2013), "Prototype didefinisikan sebagai alat yang memberikan ide bagi pembuat maupun pemakai potensial tentang cara sisttem berfungsi dalam bentuk lengkapnya, dan proses untuk menghasilkan sebuah prototype disebut prototyping. Dibawah ini adalah merupakan gambaran dari model konseptual metode prototyping.

a. Pengumpulan Kebutuhan. Peneliti dan manajemen bersama-sama mendefinisikan format seluruh perangkat lunak, mengidentifikasikan semua kebutuhan, dan garis besar sistem yang akan dibuat.

b. Membangun prototyping. Membangun prototyping dengan membuat perancangan sementara yang berfokus pada penyajian kepada manajemen (misalnya dengan membuat input dan format output).

c. Evaluasi protoptyping. Evaluasi ini dilakukan oleh pelanggan apakah prototyping yang sudah dibangun sudah sesuai dengan keinginann manajemen. Jika sudah sesuai maka langkah 4 akan diambil. Jika tidak prototyping direvisi dengan mengulang langkah a, b, dan c.

d. Mengkodekan sistem. Dalam tahap ini prototyping yang sudah di sepakati diterjemahkan ke dalam bahasa pemrograman yang sesuai

e. Menguji sistem. Setelah sistem sudah menjadi suatu perangkat lunak yang siap pakai, harus dites dahulu sebelum digunakan.

f. Evaluasi Sistem. Pelanggan mengevaluasi apakah sistem yang sudah jadi sudah sesuai dengan yang diharapkan. Jika ya, langkah g dilakukan; jika tidak, ulangi langkah d dan e.

g. Menggunakan sistem. Perangkat lunak yang telah diuji dan diterima pelanggan siap untuk digunakan.

\section{Desain Ujicoba}

Dalam penelitian pengembangan penentuan PIC teknisi ini ada satu tahap pengujian, adapun tahapan tersebut adalah :

a. Uji Coba Ahli Sistem Informasi

Pengujian kepada ahli sistem informasi untuk meriview produk awal sistem, uji coba dilakukan dengan menyebarkan kuisioner.

b. Uji Coba Pengguna

Pengujian kepada pengguna dilakukan untuk mengetahui kelayakan dan ketepatan informasi yang dihasilkan, uji coba dilakukan dengan menyebarkan kuesioner.

\section{Instrumen Penelitian}

Terdapat 2 macam jenis pertanyaan pada angket atau kuisioner kedua, yaitu jenis pertanyaan tertutup dan jenis pertanyaan terbuka. Jenis pertanyaan tertutup berisi pertanyaan - pertanyaan untuk mengetahui kualitas produk dan fitur - fitur serta fungsionalitas - fungsionalitas sistem perangkat lunak secara keseluruhan, sementara jenis jenis pertanyaan terbuka berisi saran atau kritik terkait dengan produk yang dikembangkan.

a. Instrumen Untuk Ahli

Tabel 1. Instrumen Untuk Ahli

\begin{tabular}{|l|l|c|c|}
\hline \multirow{2}{*}{ No. } & \multicolumn{1}{|c|}{ Pertanyaan } & \multicolumn{2}{c|}{ Alt Jawaban } \\
\cline { 3 - 4 } & \multicolumn{1}{|c|}{ Karakter : Functionality } & Tidak \\
\hline 1. & $\begin{array}{l}\text { Kemampuan Perangkat Lunak untuk menyediakan serangkaian fungsi } \\
\text { yang sesuai untuk tugas-tugas tertentu dan tujuan pengguna }\end{array}$ & \\
\hline 2. & $\begin{array}{l}\text { Kemampuan perangat lunak dalam menerikan hasil yng presisi dan } \\
\text { benar sesuai kebutuhan }\end{array}$ & & \\
\hline 3. & $\begin{array}{l}\text { Kemampuan perangkat lunak untuk mencegah akses yang tiddak } \\
\text { diinginkan, menghadapi penyusup (hacker) maupun otorisasi dalam } \\
\text { modifikasi data }\end{array}$ & \multicolumn{1}{|c|}{ Karakter : Reliability } \\
\hline
\end{tabular}


Volume 11 Number 1 May 2021 Page. 39-50

Journal Homepage : http://teknois.stikombinaniaga.ac.id/index.php/JBS

DOI Link : http://doi.org/10.36350/jbs.v11i1

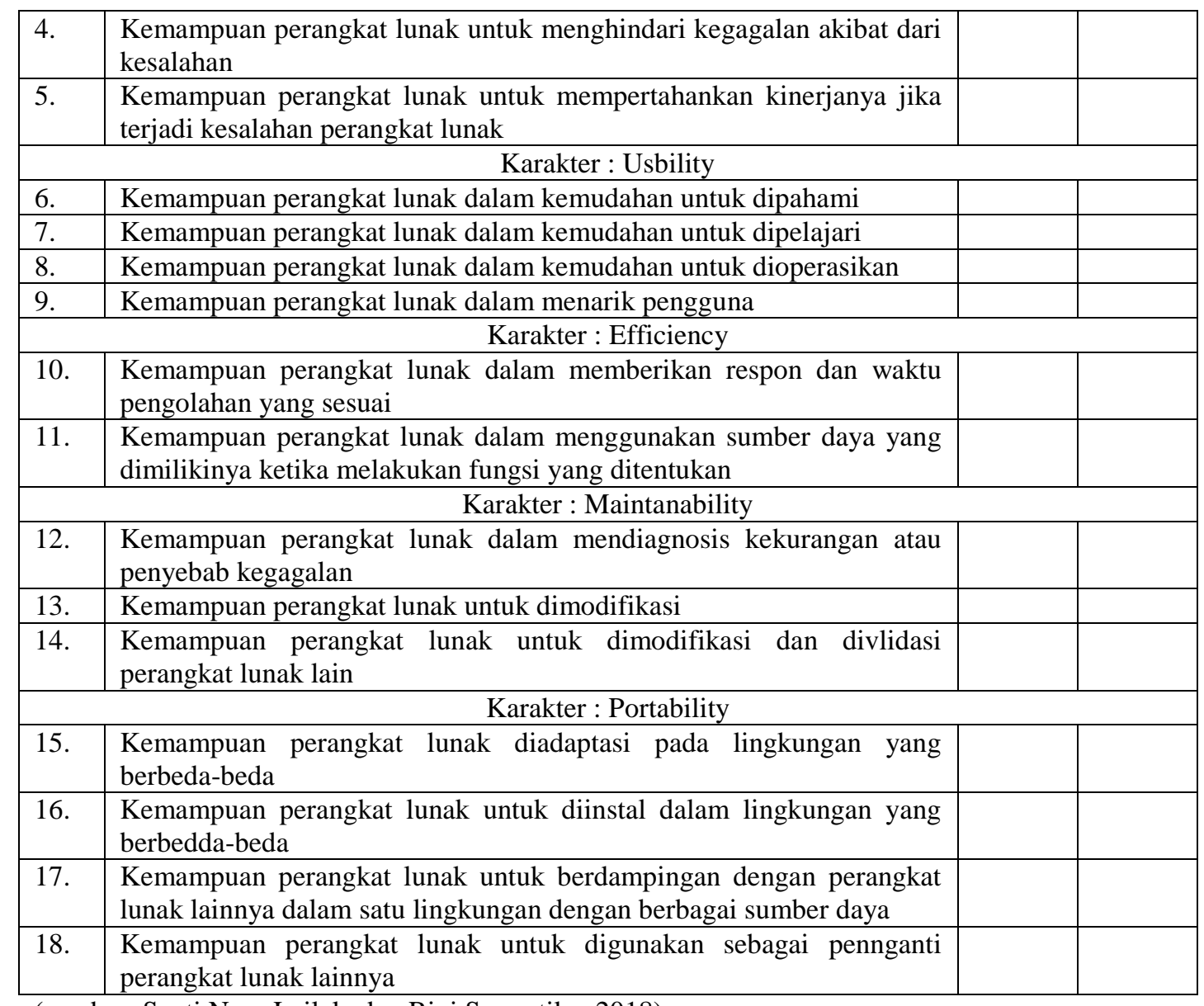

(sumber: Septi Noer Lailela dan Rini Suwartika, 2018)

b. Instrumen Untuk Pengguna

Tabel 2. Instrumen Untuk Pengguna

\begin{tabular}{|c|c|c|c|c|c|c|}
\hline No. & Pertanyaan & STS & TS & $\mathrm{N}$ & $\mathrm{S}$ & $\mathrm{SS}$ \\
\hline \multicolumn{7}{|c|}{ Operability } \\
\hline 1. & $\begin{array}{l}\text { Secara keseluruhan, saya merasa puas dengan } \\
\text { kemudahan penggunaan sistem ini. }\end{array}$ & & & & & \\
\hline 2. & Cara penggunaan sistem ini sangat simpel & & & & & \\
\hline 3. & $\begin{array}{l}\text { Saya dapat menyelesaikan tugas saya dengan efektif } \\
\text { ketika menggunakan sistem ini. }\end{array}$ & & & & & \\
\hline 4. & $\begin{array}{l}\text { Saya dapat dengan cepat menyelesaikan pekerjaan saya } \\
\text { menggunakan sistem ini. }\end{array}$ & & & & & \\
\hline 5. & $\begin{array}{l}\text { Saya dapat menyelesaikan tugs saya dengan efisien } \\
\text { ketika menggunakan sistem ini. }\end{array}$ & & & & & \\
\hline 6. & Saya merasa nyaman menggunakan sistem ini. & & & & & \\
\hline \multicolumn{7}{|c|}{ Learnability } \\
\hline 7. & Sistem ini sangat mudah dipelajari. & & & & & \\
\hline 8. & $\begin{array}{l}\text { Saya yakin saya akan lebih produktif ketika } \\
\text { menggunakan sistem ini. }\end{array}$ & & & & & \\
\hline 9. & $\begin{array}{l}\text { Jika terjadi error, sistem ini memberikan pesan } \\
\text { pemberitahuan tentang langkah yang saya lakukan untuk } \\
\text { mengatasi masalah. }\end{array}$ & & & & & \\
\hline 10. & $\begin{array}{l}\text { Kapanpun saya melakukan kesalahan, saya bisa kembali } \\
\text { dan pulih dengan cepat. }\end{array}$ & & & & & \\
\hline 11. & Informasi yang disediakan sistem ini sangat jelas. & & & & & \\
\hline 12. & $\begin{array}{l}\text { Mudah untuk menemukan informasi yang saya } \\
\text { butuhkan. }\end{array}$ & & & & & \\
\hline \multicolumn{7}{|c|}{ Understandbility } \\
\hline 13. & Informasi yang diberikan oleh sistem ini sangat mudh & & & & & \\
\hline
\end{tabular}


Volume 11 Number 1 May 2021 Page. 39-50

Journal Homepage : http://teknois.stikombinaniaga.ac.id/index.php/JBS

DOI Link : http://doi.org/10.36350/jbs.v11i1

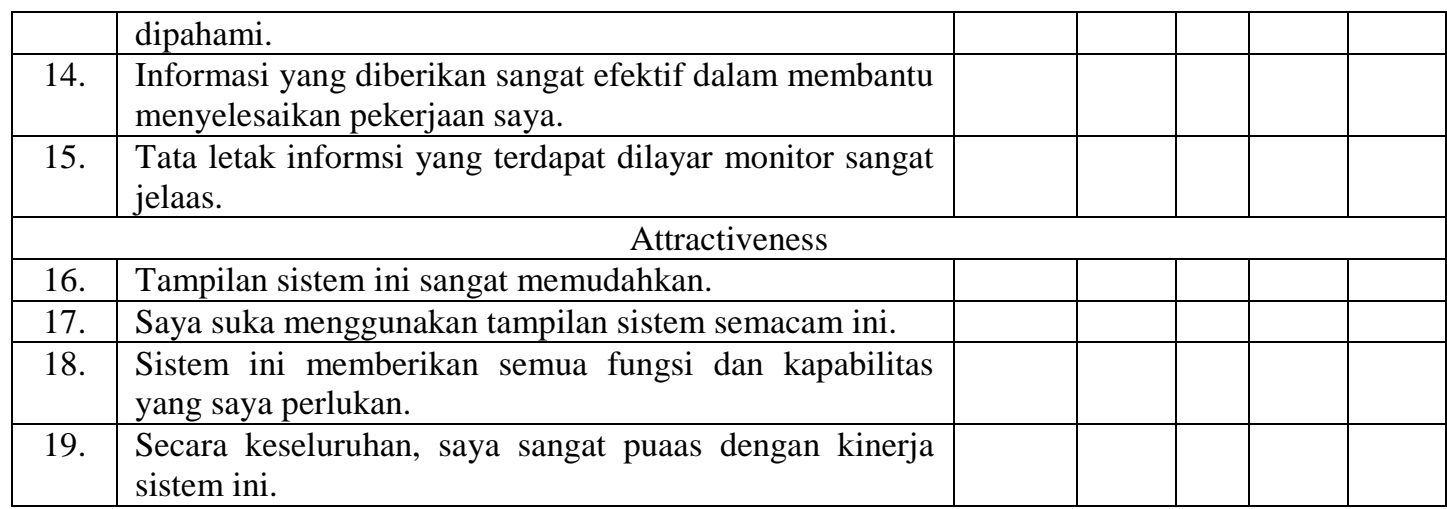

\section{Teknik Analisa Data}

Dalam penelitian ini metode analisis data dengan menggunakan presentasi kelayakan. Adapun rumus yang digunakan adalah sebagai berikut :

$$
\text { Presentasi kelayakan (\%) }=\frac{\text { skoryang diobservasi }}{\text { Skoryang ditharapkan }} \times 100 \%
$$

Hasil presentase digunakan untuk memberikan jawaban atas kelayakan atas aspek-aspek yang diteliti. Menurut Arikunto (2009, p.44), pembagian kategori kelayakan ada lima. Skala ini memperhatikan rentang dari bilangan persentase. Nilai maksimal yang diharapkan adalah $100 \%$ dan minimum 0\%. Pembagian rentang kategori kelayakan menurut Arikunto (2009, p.44),

Tabel 3. Interpretasi Persentase Kelayakan

\begin{tabular}{|c|c|}
\hline Persentase Pencapaian & Interpretasi \\
\hline$<21 \%$ & Sangat Tidak Layak \\
\hline $21 \%-40 \%$ & Tidak Layak \\
\hline $41 \%-60 \%$ & Cukup Layak \\
\hline $61 \%-80 \%$ & Layak \\
\hline $81 \%-100 \%$ & Sangat Layak \\
\hline
\end{tabular}

(Sumber : Arikunto, 2009, p.44)

\section{HASIL DAN PEMBAHASAN}

\section{Hasil}

\section{a. Analisa Produk}

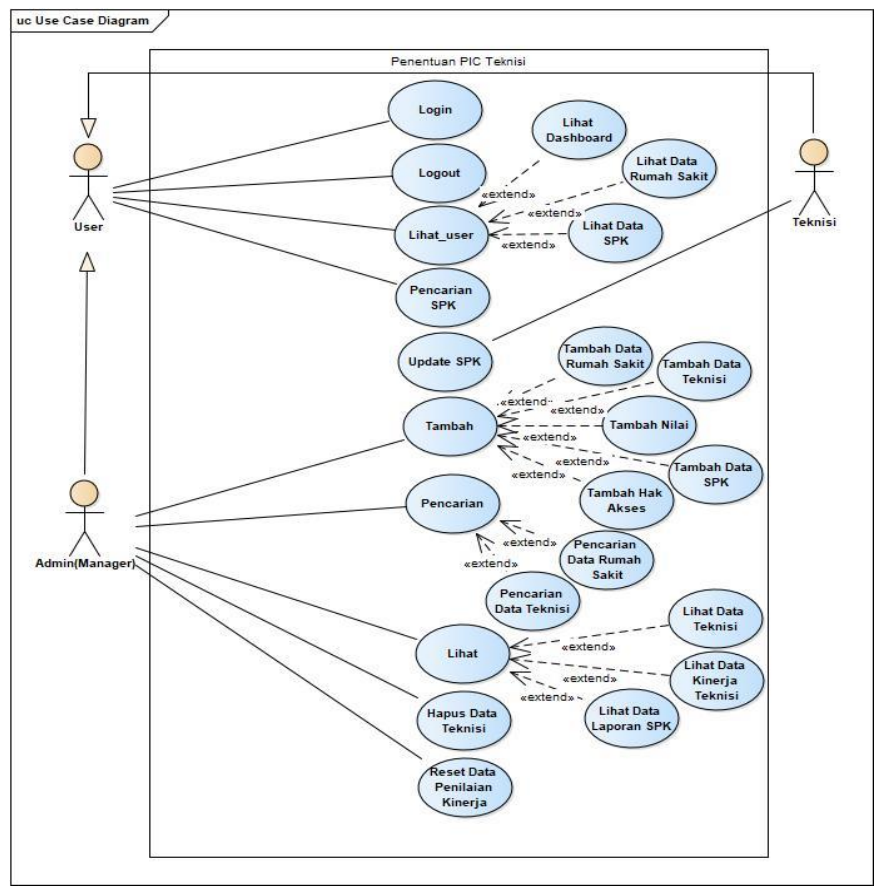

Gambar 1. Usecase Diagram 
Volume 11 Number 1 May 2021 Page. 39-50

Journal Homepage : http://teknois.stikombinaniaga.ac.id/index.php/JBS

DOI Link : http://doi.org/10.36350/jbs.v11i1

Pada gambar 1 merupakan usecase diagram yang dilihat dari proses bisnis baru sistem pendukung keputusan penentuan PIC teknisi. Terdapat satu aktor dalam sistem yaitu Manager Teknisi. Manager teknisi dapat melakukan login, logout, tambah rumah sakit, tambah teknisi, tambah penilaian teknisi dan tambah SPK.

\section{b. Analisa Kriteria}

Dalam sistem pendukung keputusan untuk menentukan PIC teknisi untuk perbaikan alat menggunakan metode perbandingan eksponensial, harus ditambahkan kriteria dan sub kriteria beserta bobot dan nilainya. Data kriteria didapatkan dari ketentuan yang sudah ada dari PT. MRK Diagnostics dan hasil wawancara dengan manager teknisi.

Tabel 4. Data Kriteria

\begin{tabular}{|c|l|c|c|}
\hline No & \multicolumn{1}{|c|}{ Nama Kriteria } & Bobot & Kode \\
\hline 1 & Keahlian & 5 & KH \\
\hline 2 & Disiplin & 4 & DS \\
\hline 3 & Komunikasi & 4 & KM \\
\hline 4 & Masa Kerja & 2 & MK \\
\hline
\end{tabular}

Tabel 5. Data Sub Kriteria

\begin{tabular}{|c|l|l|c|c|}
\hline No & Nama Kriteria & \multicolumn{1}{|c|}{ Sub Kriteria } & Nilai & Kode \\
\hline \multirow{4}{*}{1.} & \multirow{3}{*}{ Keahlian } & Test Tertulis & $1 \mathrm{~s} / \mathrm{d} 10$ & KH1 \\
\cline { 3 - 5 } & & Test Praktek & $1 \mathrm{~s} / \mathrm{d} 10$ & KH2 \\
\cline { 3 - 5 } & & Tes Lisan & $1 \mathrm{~s} / \mathrm{d} 10$ & KH3 \\
\hline \multirow{2}{*}{2.} & \multirow{3}{*}{ Disiplin } & Disiplin Tanggung Jawab & $1 \mathrm{~s} / \mathrm{d} 10$ & DS1 \\
\cline { 3 - 5 } & & Disiplin Waktu & $1 \mathrm{~s} / \mathrm{d} 10$ & DS2 \\
\hline \multirow{2}{*}{3.} & \multirow{2}{*}{ Komunikasi } & Aktif & 8 & KM1 \\
\cline { 3 - 5 } & & Pasif & 7 & KM2 \\
\hline \multirow{3}{*}{4.} & \multirow{3}{*}{ Masa Kerja } & $\leq 2$ Tahun & 9 & MK1 \\
\cline { 3 - 5 } & & 2 Tahun s/d 5 Tahun & MK3 \\
\cline { 3 - 5 } & & $\geq 5$ Tahun & & \\
\hline
\end{tabular}

\section{c. Analisa Metode}

Pada sistem pendukung keputusan untuk menentukan PIC teknisi untuk perbaikan alat metode yang digunakan adalah metode perbandingan eksponensial. Cara kerja metode perbandingan eksponensial yaitu melakukan perhitungan nilai sub kriteria yang dimiliki oleh setiap karyawan teknisi dengan memangkatkan nilai kriteria kepada bobot kriteria yang dimiliki.

Tabel 6. Data Nilai Kriteria

\begin{tabular}{|l|l|c|c|c|c|c|c|c|}
\hline No. & Nama & KH1 & KH2 & KH3 & DS1 & DS2 & KM1 & MK1 \\
\hline 1. & Donny Eko & 8 & 8 & 8 & 8 & 8 & 8 & 9 \\
\hline 2. & Ferliansyah & 9 & 8 & 8 & 9 & 8 & 8 & 9 \\
\hline 3. & Munjin Safit & 8 & 8 & 9 & 8 & 8 & 8 & 9 \\
\hline 4. & Teguh Widodo & 8 & 7 & 8 & 8 & 7 & 8 & 9 \\
\hline 5. & Agus Irawan & 9 & 9 & 8 & 8 & 9 & 8 & 9 \\
\hline 6. & Ananta Prana & 8 & 8 & 8 & 7 & 8 & 8 & 9 \\
\hline 7. & Ryan Larapati & 8 & 8 & 7 & 8 & 7 & 8 & 8 \\
\hline 8. & Syamsur Rijal & 7 & 8 & 7 & 8 & 7 & 7 & 8 \\
\hline 9. & Eri Minarto & 7 & 8 & 8 & 7 & 8 & 8 & 8 \\
\hline 10. & Hendra Eka & 7 & 7 & 7 & 8 & 8 & 7 & 8 \\
\hline 11. & Abdurrahman F & 8 & 7 & 7 & 8 & 9 & 7 & 8 \\
\hline 12. & Daniel Ricky & 7 & 7 & 7 & 7 & 7 & 8 & 7 \\
\hline 13. & Yohannes & 7 & 7 & 7 & 8 & 7 & 8 & 7 \\
\hline 14. & M. Ridho & 7 & 7 & 7 & 7 & 7 & 7 & 7 \\
\hline
\end{tabular}

Dari hasil perhitungan diatas adalah dengan cara membangi rata dengan nilai dari subkriterianya masing-masing. Setelah mendapatkan nilai dari perhitungan nilai rata-rata 
Volume 11 Number 1 May 2021 Page. 39-50

Journal Homepage : http://teknois.stikombinaniaga.ac.id/index.php/JBS

DOI Link : http://doi.org/10.36350/jbs.v11i1

dari subkriteria, maka dapat di pangkatkan dengan nilai bobot yang telah ditetapkan oleh perusahaan.

Keahlian $=(\mathrm{KH} 1+\mathrm{KH} 2+\mathrm{KH} 3) / 3$

Disiplin $=(\mathrm{DS} 1+\mathrm{DS} 2) / 2$

$\mathrm{Tn}=\mathrm{KH}^{5}+\mathrm{DS}^{4}+\mathrm{KM}^{4}+\mathrm{MK}^{2}$

Tabel 7. Data Perhitungan

\begin{tabular}{|l|l|c|c|c|c|c|c|}
\hline No. & Nama & Keahlian & Disiplin & Komunikasi & $\begin{array}{l}\text { Masa } \\
\text { Kerja }\end{array}$ & $\begin{array}{l}\text { Nilai } \\
\text { Alternatif }\end{array}$ & Prioritas \\
\hline 1. & Donny Eko & 8.0 & 8.0 & 8.0 & 9.0 & $41,041.00$ & 4 \\
\hline 2. & Ferliansyah & 8.3 & 8.5 & 8.0 & 9.0 & $49,584.82$ & 2 \\
\hline 3. & Munjin Safit & 8.3 & 8.0 & 8.0 & 9.0 & $48,460.76$ & 3 \\
\hline 4. & Teguh Widodo & 7.7 & 7.5 & 8.0 & 9.0 & $33,828.07$ & 6 \\
\hline 5. & Agus Irawan & 8.7 & 8.5 & 8.0 & 9.0 & $58,291.61$ & 1 \\
\hline 6. & Ananta Prana & 8.0 & 7.5 & 8.0 & 9.0 & $40,109.06$ & 5 \\
\hline 7. & Ryan Larapati & 7.7 & 7.5 & 8.0 & 8.0 & $33,811.07$ & 7 \\
\hline 8. & Syamsur Rijal & 7.3 & 7.5 & 7.0 & 8.0 & $26,837.42$ & 10 \\
\hline 9. & Eri Minarto & 7.7 & 7.5 & 8.0 & 8.0 & $33,811.07$ & 8 \\
\hline 10. & Hendra Eka & 7.0 & 8.0 & 7.0 & 8.0 & $23,368.00$ & 12 \\
\hline 11. & Abdurrahman F & 7.3 & 8.5 & 7.0 & 8.0 & $28,893.42$ & 9 \\
\hline 12. & Daniel Ricky & 7.0 & 7.0 & 8.0 & 7.0 & $23,353.00$ & 13 \\
\hline 13. & Yohannes & 7.0 & 7.5 & 8.0 & 7.0 & $24,116.06$ & 11 \\
\hline 14. & M. Ridho & 7.0 & 7.0 & 7.0 & 7.0 & $21,658.00$ & 14 \\
\hline
\end{tabular}

\section{d. Produk}

1) Menu Teknisi

Gambar 2 merupakan menu dimana nama-nama karyawan teknisi. Jika ingin menambahkan teknisi, admin dapat melakukan click pada tulisan tambah. Dan apabila ingin menilai kinerja teknisi bisa click nilai.

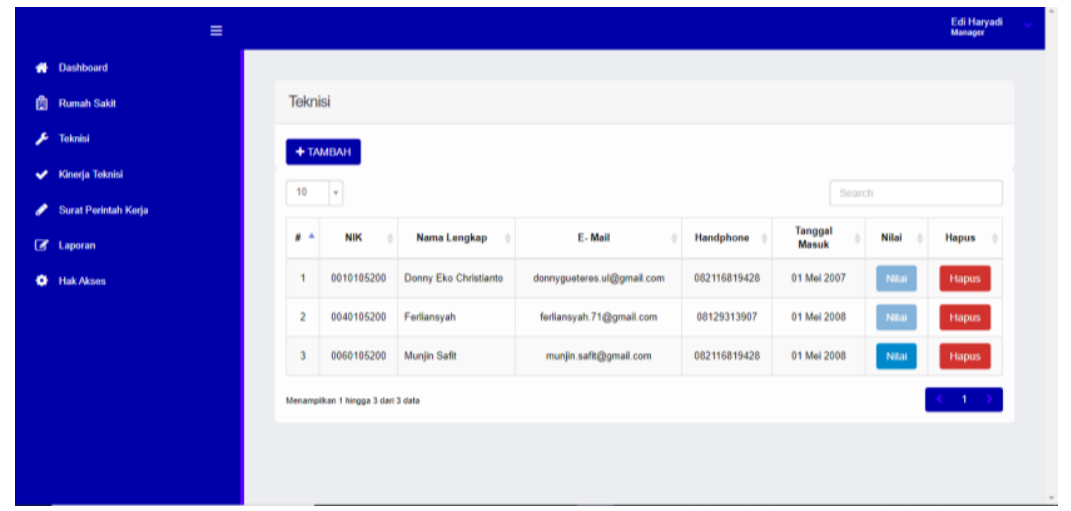

Gambar 2. Menu Teknisi

2) Menu Nilai Kinerja

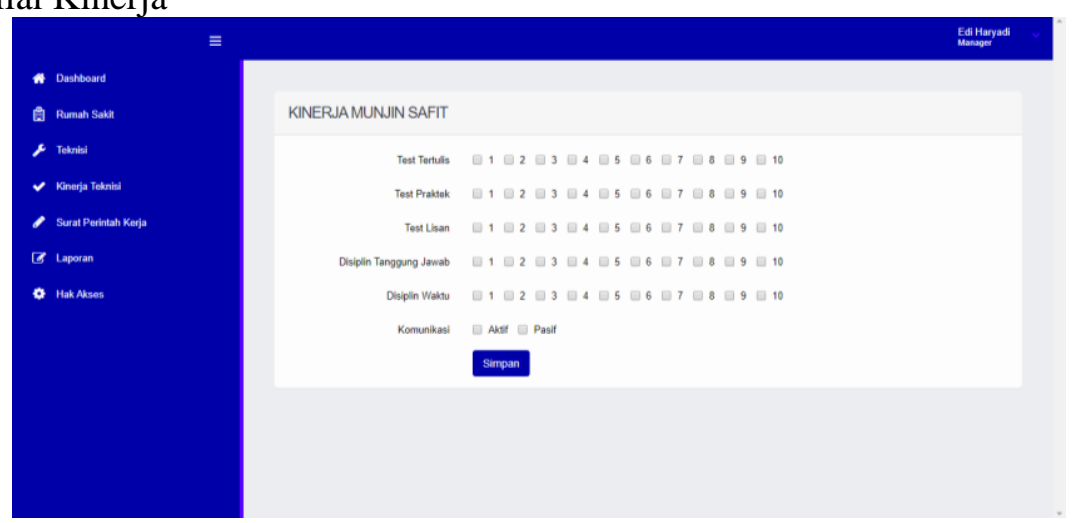

Gambar 3. Menu Nilai Kinerja 
Volume 11 Number 1 May 2021 Page. 39-50

Journal Homepage : http://teknois.stikombinaniaga.ac.id/index.php/JBS

DOI Link : http://doi.org/10.36350/jbs.v11i1

Gambar 3 disini admin bisa melakukan input nilai kinerja teknisi yang akan ditambahkan.

3) Menu Kinerja Teknisi

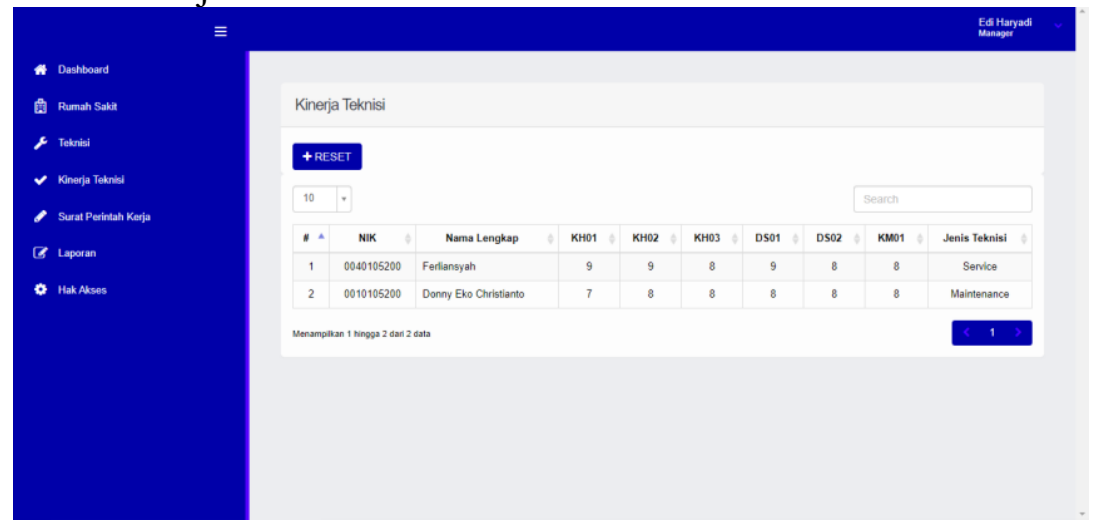

Gambar 4. Menu Kinerja Teknisi

Gambar 4 merupakan menu dimana admin bisa melihat nilai-nilai kinerja teknisi yang sudah diberikan.

\section{Pembahasan}

a. Hasil Kuesioner Ahli Sistem Informasi

Tabel 8. Rekapitulasi Kuesioner Ahli

\begin{tabular}{|c|c|c|c|}
\hline \multirow[t]{2}{*}{ NO } & \multirow{2}{*}{ Pernyataan } & \multicolumn{2}{|c|}{ Responden } \\
\hline & & R1 & $\mathbf{R 2}$ \\
\hline \multicolumn{4}{|c|}{ Functionality } \\
\hline 1 & Suitability / kesesuaian & 1 & 0 \\
\hline 2 & Acurateness / keakuratan & 1 & 1 \\
\hline 3 & Securit / keamanan & 1 & 1 \\
\hline \multicolumn{4}{|c|}{ Reability } \\
\hline 4 & Maturity / maturitas & 1 & 1 \\
\hline 5 & Fault Tolerance / Toleransi kesalahan & 1 & 1 \\
\hline \multicolumn{4}{|c|}{ Usaability } \\
\hline 6 & Ubnderstndability & 1 & 1 \\
\hline 7 & Learnability & 1 & 1 \\
\hline 8 & Operability & 1 & 1 \\
\hline 9 & Attractiveness & 1 & 1 \\
\hline \multicolumn{4}{|c|}{ Efficiency } \\
\hline 10 & Time Behaviour & 1 & 1 \\
\hline 11 & Resource Utilization & 1 & 1 \\
\hline \multicolumn{4}{|c|}{ Maintanability } \\
\hline 12 & Analysability & 1 & 1 \\
\hline 13 & Changeability & 1 & 1 \\
\hline 14 & Tetstability & 1 & 0 \\
\hline \multicolumn{4}{|c|}{ Portability } \\
\hline 15 & Adaptability & 1 & 1 \\
\hline 16 & Instability & 1 & 1 \\
\hline 17 & Coexistence & 1 & 0 \\
\hline 18 & Replaceability & 1 & 1 \\
\hline \multirow{2}{*}{\multicolumn{2}{|c|}{$\begin{array}{c}\text { Total Skor } \\
\text { Total }\end{array}$}} & 18 & 15 \\
\hline & & \multicolumn{2}{|c|}{33} \\
\hline
\end{tabular}

Persentase kelayakan $(\%)=\frac{\text { skor yang diobservasi }}{\text { skor yang diharapkan }} \times 100 \%$

Persentase kelayakan $(\%)=\frac{33}{36} \times 100 \%$ 
Volume 11 Number 1 May 2021 Page. 39-50

Journal Homepage : http://teknois.stikombinaniaga.ac.id/index.php/JBS

DOI Link : http://doi.org/10.36350/jbs.v11i1

\section{Persentase kelayakan $(\%)=91,7 \%$}

Persentase kelayakan yang di dapat sebesar 91,7\%, maka dapat dikategorikan ke dalam interpretasi yang "Sangat Layak" seperti yang ditunjukkan pada tabel 3.

b. Hasil Kuesioner Pengguna

Tabel 9. Rekapitulasi Kuesioner Pengguna

\begin{tabular}{|c|c|c|c|c|c|}
\hline \multirow[t]{2}{*}{ No } & \multirow[t]{2}{*}{ Pernyataan } & \multicolumn{4}{|c|}{ Responden } \\
\hline & & $\mathbf{R 1}$ & $\mathbf{R 2}$ & R3 & $\mathbf{R 4}$ \\
\hline \multicolumn{6}{|c|}{ Operability } \\
\hline 1 & Pertanyaan 1 & 4 & 4 & 4 & 4 \\
\hline 2 & Pertanyaan 2 & 5 & 4 & 4 & 5 \\
\hline 3 & Pertanyaan 3 & 4 & 4 & 4 & 3 \\
\hline 4 & Pertanyaan 4 & 4 & 4 & 4 & 4 \\
\hline 5 & Pertanyaan 5 & 4 & 4 & 4 & 4 \\
\hline 6 & Pertanyaan 6 & 4 & 5 & 4 & 4 \\
\hline \multicolumn{6}{|c|}{ Learnability } \\
\hline 7 & Pertanyaan 7 & 4 & 4 & 4 & 4 \\
\hline 8 & Pertanyaan 8 & 4 & 4 & 4 & 4 \\
\hline 9 & Pertanyaan 9 & 3 & 4 & 3 & 3 \\
\hline 10 & Pertanyaan 10 & 4 & 4 & 4 & 4 \\
\hline 11 & Pertanyaan 11 & 4 & 4 & 4 & 4 \\
\hline 12 & Pertanyaan 12 & 4 & 4 & 3 & 4 \\
\hline \multicolumn{6}{|c|}{ Understandbility } \\
\hline 13 & Pertanyaan 13 & 5 & 4 & 4 & 4 \\
\hline 14 & Pertanyaan 14 & 4 & 4 & 4 & 4 \\
\hline 15 & Pertanyaan 15 & 4 & 4 & 4 & 4 \\
\hline \multicolumn{6}{|c|}{ Attractiveness } \\
\hline 16 & Pertanyaan 16 & 5 & 4 & 4 & 4 \\
\hline 17 & Pertanyaan 17 & 4 & 4 & 4 & 4 \\
\hline 18 & Pertanyaan 18 & 4 & 4 & 4 & 4 \\
\hline 19 & Pertanyaan 19 & 4 & 4 & 4 & 4 \\
\hline \multicolumn{2}{|r|}{ Jumlah } & 78 & 77 & 74 & 75 \\
\hline & Skor Yang Diharapkan & 95 & 95 & 95 & 95 \\
\hline
\end{tabular}

$$
\begin{aligned}
\text { Persentase kelayakan }(\%) & =\frac{\text { skor yang diobservasi }}{\text { skor yang diharapkan }} X 100 \% \\
\text { Persentase kelayakan }(\%) & =\frac{78+77+73+75}{95+95+95+95} X 100 \% \\
\text { Persentase kelayakan }(\%) & =80 \%
\end{aligned}
$$

Dilihat dari tabel kategori kelayakan nila presentase kelayakan $80 \%$ berada dalam kategori sangat layak, dengan demikian sistem pendukung keputusan untuk menentukan person in charge teknisi menggunakan metode perbandingan eksponensial dinyatakan sangat layak.

\section{KESIMPULAN}

Berdasarkan hasil penelitian yang dilakukan, kesimpulan yang bisa diuraikan antara lain :

1. Dapat memberikan hasil penentuan PIC teknisi menjadi lebih efektif berdasarkan prioritas yang diambil dari kriteria keahlian, disiplin, komunikasi dan masa kerja.

2. Dapat memberikan hasil penentuan PIC menjadi lebih efektif, hal ini berdasarkan hasil uji kelayakan sistem yang dilakukan oleh pengguna dengan nilai presentase sebesar $80 \%$ yang artinya sistem ini dikatakan sangat layak.

3. Sistem yang dikembangkan dengan menerapkan metode perbandingan eksponensial ini dikatakan sangat layak karena berdasarkan hasil uji kelayakan yang dilakukan oleh ahli sistem mendapatkan nilai presentase sebesar 91,7\%. 


\section{E. DAFTAR PUSTAKA}

[1] Arikunto, Suharsimi. (2009). Manajemen Penelitian, edisi Revisi. Jakarta : Rineka Cipta

[2] Gondodiyoto, Sanyoto. (2007). Audit Sistem Informasi + Pendekatan CobIT. Mitra Wacana Media.

[3] Lailela, S. N., \& Kusumadiarti, R. S. (2018). PENGUKURAN KUALITAS PERANGKAT LUNAK APLIKASI SISFO_NILAI DI POLITEKNIK PIKSI GANESHA BERDASARKAN ISO 9126. Jurnal E-Komtek (Elektro-Komputer-Teknik), 2(2), 84 - 100. https://doi.org/10.37339/e-komtek.v2i2.96

[4] Pratiwi, H. (2016). Buku Ajar Sistem Pendukung Keputusan. Sistem Pendukung Keputusan. https://doi.org/10.1063/1.1935433

[5] Pressman, RS. (2012).Rekayasa Perangkat Lunak. Yogyakarta : Andi

[6] Raymond McLeod, J. (2001). Sistem Informasi Manajamen. Management Information System. https://doi.org/9780749428310

[7] Supriyatna, Alam, and Fauzan Y. Ibrahim. "Penerapan Metode Profile Matching untuk Menentukan Peserta Lomba Pramuka." Teknois, vol. 8, no. 2, Nov. 2018, pp. 15-24, doi:10.36350/jbs.v8i2.11.

[8] Sugiyono, P. D. metode penelitian kuantitatif, kualitatif,dan R\&D., Alfabeta, cv. (2016).

[9] Utari, Lis, and Ika Merina. "Penentuan Kenaikan Level pada Karyawan dengan Penerapan Metode Profile Matching." Teknois, vol. 9, no. 2, 30 Nov. 2019, pp. 65-78, doi:10.36350/jbs.v9i2.67. 